\title{
Ghrelin in gastrointestinal diseases and disorders: A possible role in the pathophysiology and clinical implications (Review)
}

\author{
MAGDY EL-SALHY \\ Section for Gastroenterology, Institute of Internal Medicine, University of Bergen and Stord Helse-Fonna Hospital, Norway
}

Received June 22, 2009: Accepted August 12, 2009

DOI: 10.3892/ijmm_00000285

\begin{abstract}
Ghrelin is a peptide hormone, which has been isolated from the stomach. It is localized mostly in endocrine cells in the oxyntic mucosa of the stomach. Ghrelin receptors are expressed equally in all parts of the gastrointestinal tract, with a similar level of expression in the mucosal and muscle layers. This peptide hormone has several functions, the most widely known is its growth hormone (GH)-releasing effect. Ghrelin plays an important role in regulating appetite, feeding and energy metabolism. It also plays a role in mediating immune response and inflammatory processes. Ghrelin stimulates gastric motility and emptying as well as motility in the small and large intestine. Ghrelin has been reported to be affected in several gastrointestinal diseases/disorders such as inflammatory bowel disease, coeliac disease, infectious diseases, functional disorders and diabetes gastroenteropathy. This indicates that ghrelin is involved in the pathophysiology of gastrointestinal diseases/disorders. Several studies have shown that ghrelin and its antagonist are a promising tool for treatment of several gastrointestinal diseases/disorders.
\end{abstract}

\section{Contents}

1. Introduction

2. Inflammatory and infectious gastrointestinal diseases

3. Functional gastrointestinal disorders

4. Diabetes gastroentropathy

5. Neoplasia

6. Bariatric surgery

7. Conclusion

\section{Introduction}

Ghrelin is a 28-amino acid peptide hormone, which has been isolated from the stomach (1). Ghrelin originates mostly from

Correspondence to: Professor Magdy El-Salhy, Section for Gastroenterology, Medicine Clinic, Stord Helse-Fonna Hospital, PO Box 4000, 5409 Stord, Norway

E-mail: magdy.el-salhy@helse-fonna.no

Key words: disease, disorder, gastrointestinal tract, ghrelin, oxyntic mucosa endocrine cells in the oxyntic mucosa of the stomach, designated X/A, but small amounts of ghrelin were also found in both the small intestine and arcuated nucleus of the hypothalamus $(1,2)$. Whereas ghrelin release seems to be increased by protein and fat ingestion, its release appears to be suppressed by carbohydrate ingestion (3). Gherlin secretion in the stomach has been found to be modulated by both cholinergic and adrenergic arms of the autonomic nervous system (4). Ghrelin receptors are expressed equally in all parts of the gastrointestinal tract, with a similar level of expression in the mucosal and muscle layers (5).

Ghrelin has several functions, the best known is its growth hormone $(\mathrm{GH})$-releasing effect in the pituitary, where it acts synergistically with GH-releasing hormone $(1,6)$. Ghrelin increases appetite and feeding, and plays a major role in energy metabolism and is one of the hormones that affects body composition $(7,8)$. It also plays a role in mediating immune response and inflammatory processes $(9,10)$. Furthermore, ghrelin seems to play an important role in regulating gastrointestinal motility. Thus, gherlin stimulates gastric motility and emptying in mice, rats and humans (12-16). The stimulatory effects of ghrelin on gastric motility do not seem to be mediated via $\mathrm{GH}$ or motilin but by vagal nerve or directly on ghrelin receptors in the stomach (12). Moreover, this effect was described to be mediated by direct stimulation of the enteric neural pathway and capsaicin-sensitive afferent neurones (17). Ghrelin has also been reported to stimulate motility in the small and large intestine and shorten colonic transit time $(18,19)$. In canines, however, ghrelin did not show any stimulatory effect on the fasted and fed motor activities in the stomach, duodenum, jejenum or colon (20).

Many gastrointestinal diseases and disorders exhibit gastrointestinal dysmotility and/or inflammation. As ghrelin seems to play an important role in gastrointestinal motility and immunology, the present review was undertaken in order to shed light on the possible role of ghrelin in the pathophysiology of gastrointestinal diseases and disorders and possible clinical implications.

\section{Inflammatory and infectious gastrointestinal diseases}

Serum gherlin levels are significantly higher in patients with active ulcerative colitis (UC) and Crohn's disease (CD) than those in remission or controls (21-23). Circulating gherlin levels in UC and CD patients were positively correlated with sedimentation, C-reactive protein and fibrinogen and negatively correlated with nutritional status parameters (23). It was 
concluded that gherlin is important in determination of activity in inflammatory bowel diseases (IBD) patients and evaluation of nutritional status. Although this suggestion is attractive, there are simpler laboratory parameters that are currently used to evaluate the disease activity and the nutritional status of these patients.

Ghrelin has been reported to have potent anti-inflammatory properties through modulation of secretion of both pro- and anti-inflammatory cytokines from LPS stimulated macrophages through distinct cascades (10). It was suggested that ghrelin has therapeutic potential in controlling, modulating, or treating pathologic inflammatory conditions such as endotoxemic shock and UC. The therapeutic action of ghrelin was tested in a mouse model of colitis. In this animal model, ghrelin significantly ameliorated the clinical and histopathologic severity of the trinitrobenzene sulfonic acid-induced colitis. Thus, ghrelin treatment abrogates body weight loss, diarrhoea, inflammation and increases survival. The therapeutic effect is associated with down-regulation of both inflammatory and Th1-driven autoimmune response through the regulation of a wide spectrum of inflammatory mediators. In addition, a partial involvement of interleukin-10/transforming growth factor- $B 1$-secreting regulatory $\mathrm{T}$ cells in this therapeutic effect was demonstrated (9).

In children with coeliac disease, serum ghrelin was higher than those of controls and negatively correlated with body mass index (BMI). Ghrelin levels were lower after 6 months under a gluten-free diet compared with the levels detected on admission. Ghrelin levels were still higher compared with that of healthy children (24), though treatment with a life-long gluten-free diet caused a marked improvement or complete restoration of the intestinal mucosa. The incomplete restoring of ghrelin levels after a gluten-free diet are explained by the fact that nutritional deficiencies do not completely normalize and an increase in resting metabolic rate occur in patients with coeliac disease even after gluten-free diet treatment $(25,26)$.

In adults with coeliac disease, ghrelin levels have been reported to be higher than control subjects and became normal, compared to controls after a gluten-free diet $(27,28)$. It was reported, however, that circulating ghrelin levels were similar between 18 untreated adult women with coeliac disease and control subjects, but decreased after a gluten-free diet (29). Ghrelin cell density was found to be significantly reduced in adult patients with newly diagnosed coeliac disease (unpublished data).

It is unclear whether ghrelin levels correlate with intestinal mucosal lesion severity or not. Whereas Peracchi et al (27) reported that serum ghrelin levels correlated positively with intestinal mucosal lesion severity, Lanzini et al (28) could not confirm this observation. If the correlation between ghrelin levels and the severity of intestinal mucosal lesions in coeliac disease are proven true, that would be evidence of the involvement of ghrelin in the inflammatory process.

Whether circulating ghrelin levels in patients with autoimmune gastritis is affected is not clear. Whereas ghrelin serum levels were reported to be low, and to be the most sensitive and specific non-invasive marker for gastric body gastritis (30), ghrelin concentration decreased in patients with autoimmune atrophic gastritis and diabetes type 1 (31). In patients with chronic atrophic gastritis acetylated ghrelin
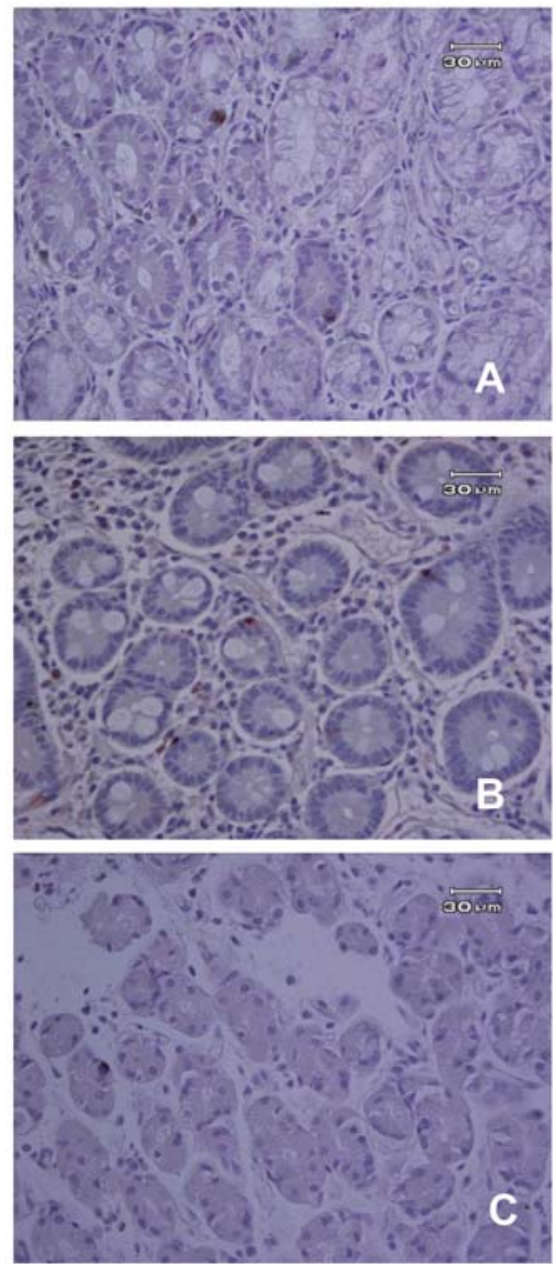

Figure 1. Ghrelin-immunoreactive cells in the oxyntic mucosa of a healthy subject (A), in a patient with IBS-diarrhoea (B) and in a patient with IBSconstipation (C).

levels increased in the gastric body and fundus. This finding was interpreted as an increase in acylating process as a compensatory process in response to gastric atrophy, a condition which causes a loss of ghrelin-producing cells and an increase in gastric $\mathrm{pH}$ (32).

Plasma ghrelin levels were reported to increase rapidly in response to E. coli endotoxin (33). On the other hand, ghrelin levels were found to fall in a state of acute inflammation brought about by injection of bacterial lipopolysaccarides (34). It was demonstrated further that the decrease in circulating ghrelin is not due to a decrease in ghrelin gene expression, but is instead likely to be due to an acute decrease in ghrelin secretion. The change in circulating ghrelin during acute inflammation required a prostaglandin second messenger, but did not require the synthesis of nitric oxide (34). It is interesting that $\operatorname{IgG}$ and $\operatorname{Ig} \mathrm{A}$ auto-antibodies against ghrelin were found in healthy women and that a sequence homology with ghrelin was identified among commercial and microorganisms (35).

Helicobacter pylori infection is associated with a reduction in circulating ghrelin levels independent of sex and BMI. Ghrelin levels increased, however, 12 weeks after successful H. pylori eradication (36-38). The density of ghrelinimmunoreactive cells was lower in the oxyntic mucosa of patients infected with $H$. pylori. This decrease is associated 


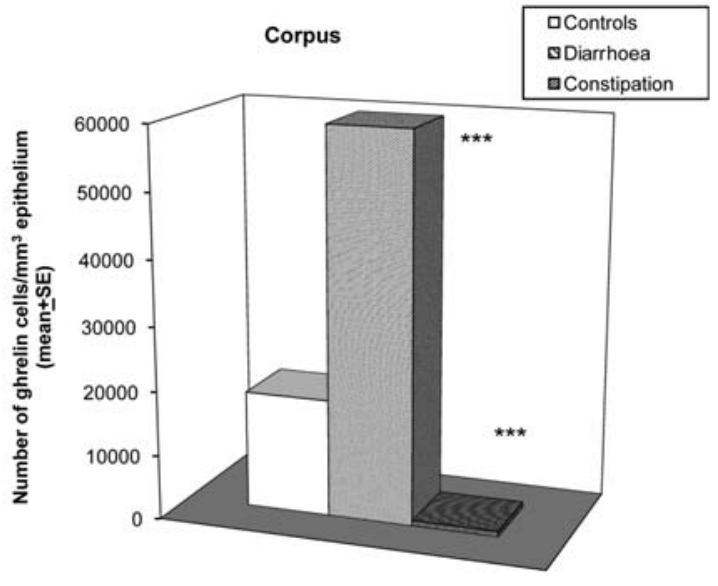

Figure 2. Ghrelin cell density in the oxytic mucosa of controls and patients with IBS.

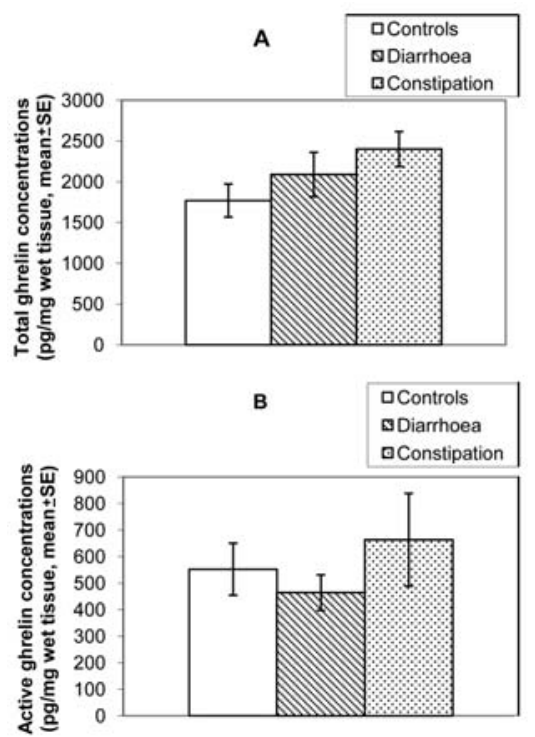

Figure 3. The concentration of total ghrelin (A) and active ghrelin (B) in tissue extracts of the oxyntic mucosa of controls and patients with IBS.

with neurtrophil activity, chronic inflammation and glandular atrophy induced by $H$. pylori infection $(36,39)$. The low level of circulating ghrelin and low density of ghrelin cells in the oxyntic mucosa is attributed to atrophic gastritis induced by $H$. pylori infection rather than to the infection process itself $(36,40)$.

\section{Functional gastrointestinal disorders}

Serum ghrelin concentration has been reported to be significantly higher in dyspeptic patients than healthy controls $(28,41)$. However, fasting desacyl and total ghrelin was found to be significantly lower in patients with functional dyspepsia of the dysmotility type than controls. On the other hand, total fasting ghrelin levels in these patients do not differ from posprandial levels in contrast to that found in controls. There is no association to the prolonged gastric emptying (42).

In irritable bowel syndrome (IBS) patients, ghrelin cell density in the oxyntic mucosa has been reported to be significantly higher in IBS-diarrhoea and lower in IBS-

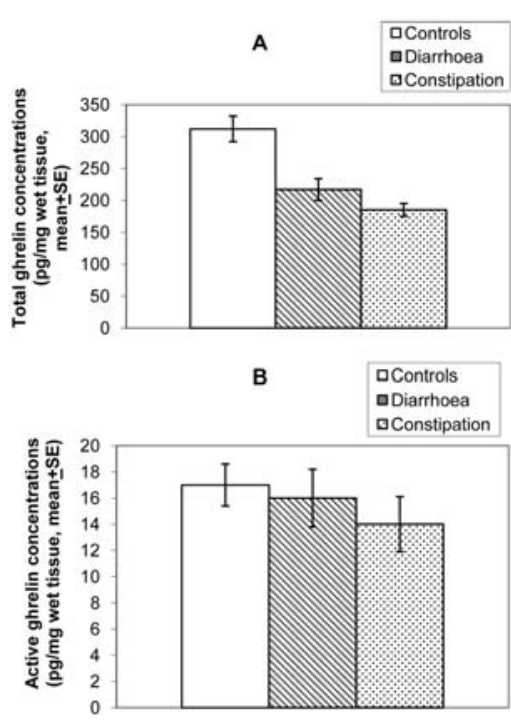

Figure 4. The total (A) and active (B) ghrelin concentration in tissue extracts of duodenal mucosa of controls and patients with IBS.

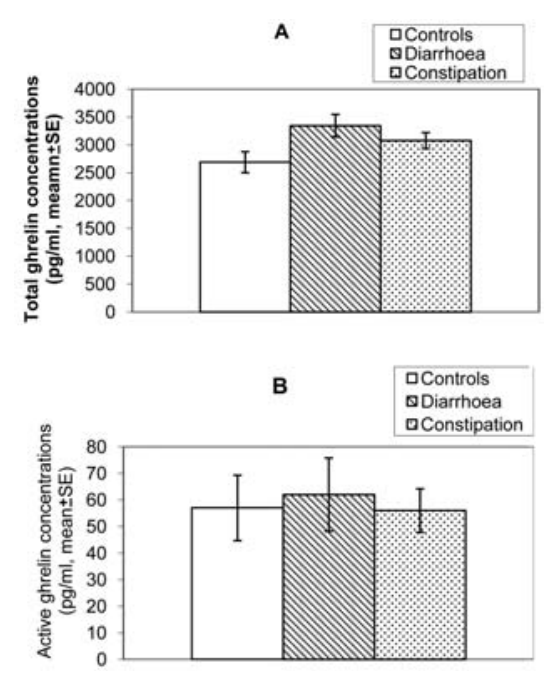

Figure 5. The levels of total ghrelin (A) and active ghrelin in the plasma of controls and in patients with IBS.

constipation patients than healthy controls (Fig. 1). The concentration of total or active ghrelin in oxyntic mucosa and duodenum extracts as well as in plasma of these patients did not differ from that of controls (43) (Figs. 2-5). It was suggested that in order to compensate for the increase and decrease in the ghrelin cell density, the synthesis of ghrelin decreased and increased in IBS-diarrhoea and -constipation patients, respectively. They speculated further, that this compensatory mechanism is subjected to fatigue from time to time resulting in increased and decreased levels of ghrelin in IBS-diarrhoea and -constipation with a subsequent intermittent diarrhoea or constipation seen in these patients, respectively (43).

\section{Diabetes gastroentropathy}

Ghrelin cell density was decreased in the oxyntic mucosa of pre-diabetic and diabetic subjects in an animal model for human diabetes type 1, NOD mice (44). In another experimental animal model of type 1 diabetes, streptozotocin-induced 


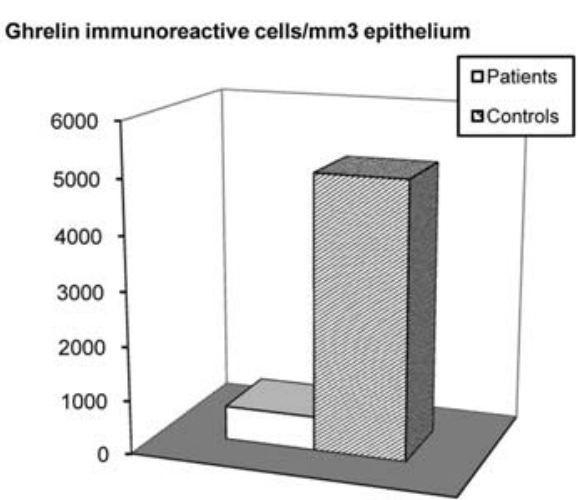

Figure 6. Ghrelin cell density in the oxyntic mucosa of controls and patients with diabetes type 1 .

diabetes in rats, the concentration of ghrelin in the gastric mucosa was low and the ghrelin plasma level high (45). Similarly, the ghrelin cell density has been reported to be low in an animal model of human diabetes type 2, obese diabetic mice (44). In patients with diabetes type 1 ghrelin cell density was low in the oxyntic mucosa (Figs. 6 and 7). The ghrelin cell density in these patients correlates negatively with gastric emptying (46). Ghrelin promotes regeneration of $\beta$ cells in streptozotocin-treated newborn rats (47).

Ghrelin injection given as a bolus dose at the end of a meal, accelerates gastric emptying in patients with diabetes and gastroparesis (48). In a randomised, double blinded, crossover study, intravenous infusion of ghrelin increased gastric emptying in patients with diabetic gastroparesis. This was independent of vagal tone (49).

\section{Neoplasia}

In patients with gastric cancer, ghrelin in the gastric mucosa is affected. Gastrectomy decreased the plasma level in these patients, regardless of the extent of gastric resection (50). Ghrelin serum levels were significantly lower in colon cancer patients than in healthy controls (51). On the other hand, Huang and co-workers (52) reported that plasma ghrelin levels did not increase significantly in cachectic gastric or colorectal cancer patients as compared with controls and were not correlated to the nutritional status.

Ghrelin immunoreactive cells have been found in gastric endocrine tumours and among the hyperplastic endocrine cells in the mucosa surrounding type I and II ECL-Ccs, where they showed diffuse, linear, nodular and adenomatoid patterns. Despite the frequent occurrence of ghrelin-immunoreactive cells in both the neoplastic parenchyma and oxyntic mucosa, plasma total ghrelin concentrations remained unchanged within the reference range and therefore cannot be used as a clinical marker to identify ghrelin expressing ECL-Ccs or ghrelin hyperplasia (53). Furthermore, ghrelin expression has been shown in 3 out of 12 neuroendocrine tumours of the gastrointestinal tract in patients with multiple endocrine neoplasia type 1 (54).

\section{Bariatric surgery}

In recent years, bariatric surgery tended to design procedures aiming at neuroendocrine changes instead of restriction and
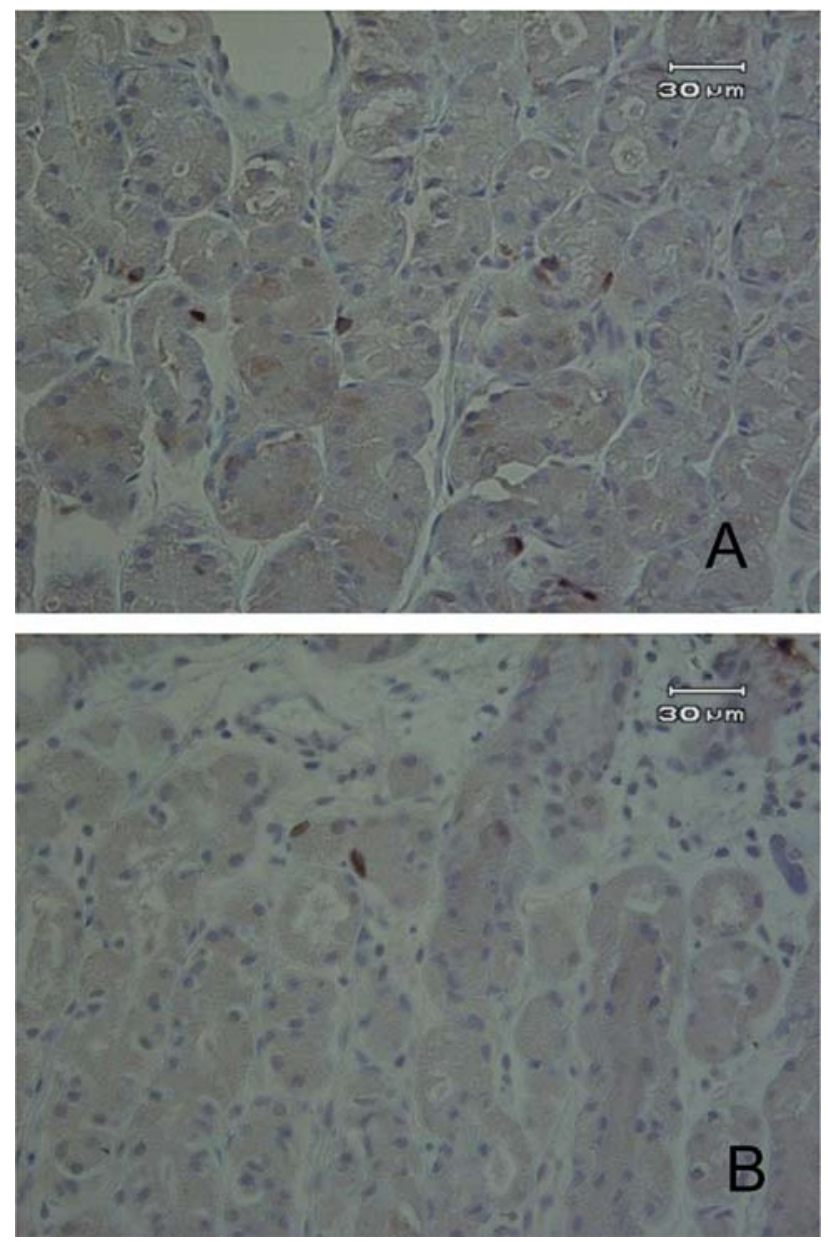

Figure 7. Ghrelin-immunoreactive cells in the oxyntic mucosa of a healthy subject (A) and in a patient with diabetes type 1 (B).

malabsorption. Since ghrelin plays an important role in regulating appetite, feeding and energy metabolism, different bariatric procedures have been evaluated with regard to this hormone.

Following Roux-Y gastric bypass, the plasma level of deacyl-ghrelin increases in non-diabetic obese patients, but not in diabetic patients (55-57). Patients operated by Roux-en-Y gastric bypass show an early and greater postprandial suppression of ghrelin level than patients operated by gastric banding (58).

The density of ghrelin-immunoreactive cells was reported to decrease 1 year following gastric banding in morbidly obese patients (59). Laparoscopic adjustable gastric banding leads to a decrease in fasting plasma ghrelin and is accompanied by a decrease of hunger (60). Unlike reducing diet or gastric bypass, following biliopancreatic diversion only an initial reduction of serum ghrelin concentration has been observed. Two months following biliopancreatic diversion, when food had nearly completely resumed, the value returned to the preoperative levels (61).

As a consequence of resection of gastric fundus, the prominent area of human ghrelin production, ghrelin is significantly reduced after laparoscopic sleeve gastrectomy but not after laparoscopic adjustable gastric banding. The reduction remains stable at follow-up for 6 months post- 
operatively, which may contribute to the superior weight loss when compared with adjustable gastric banding (62). Following the digestive adaptation procedure, fasting ghrelin was found to be significantly reduced and diabetes to be improved. A five-year followup of patients operated with this procedure did not disclose either diarrhoea or malabsorption (63).

\section{Conclusion}

Ghrelin seems to be affected in several gastrointestinal diseases/ disorders, indicating that this peptide hormone is involved in the pathophysiology of these diseases/disorders. Several studies have shown that treatment with ghrelin is effective in diabetes and idiopathic gastroparesis (64) as well as in colitis. Ghrelin and its antagonists appear therefore to be a promising tool in the treatment of gastrointestinal diseases/disorders.

\section{Acknowlegdements}

The author's works cited in this review was supported by grants from Helse-Fonna.

\section{References}

1. Kojima M, Hosoda H, Date J, Nakazato M, Matsuo H and Kangawa K: Ghrelin is growth-hormone-releasing acetylated peptide from stomach. Nature 402: 656-660, 1999.

2. Date Y, Kojima M, Hosoda H, Sawaguchi A, Mondal MS, Suganuma T, Matsukura S, Kangawa $\mathrm{K}$ and Nakazato $M$ : Ghrelin, a novel growth hormone-releasing acetylated peptide, is synthesized in a distinct endocrine cell type in the gastrointestinal tracts of rats and humans. Endocrinology 141: 4255-4261, 2000.

3. Erdmann J, Töpsch R, Lippl F, Gussmann P and Schusdziarra V: Postprandial response of plasma ghrelin levels to various test meals in relation to food intake, plasma insulin and glucose. $\mathrm{J}$ Clin Endocrinol Metab 89: 3048-3054, 2004.

4. Hosoda $\mathrm{H}$ and Kangawa $\mathrm{K}$ : The autonomic nervous system regulates gastric gherlin secretion in rats. Regul Pep 146: 12-18, 2008.

5. Takeshita E, Matsura B, Dong M, Miller LJ, Matsui H and Onji M: Molecular characterization and distribution of motilin family receptors in the human gastrointestinal tract. J Gastroenterol 41: 223-230, 2006

6. Hataya Y, Akamizu T, Takaya K, Ariyasu N, Sajjo M Moriyama K, Shimatsu A, Kojima M, Kangawa K and Nakao K A low dose of ghrelin stimulates growth hormone $(\mathrm{GH})$ release synergistically with GH-releasing hormone in humans. J Clin Endocrinol Metab 86: 4552-4555, 2001.

7. Wren AM, Seal LJ, Cohen MA, Brynes AE, Frost GS, Murphy KG, Dhillo LO, Ghatei MA and Bloom SR: Ghrelin enhances appetite and increases food intake in humans. J Clin Endocrinol Metab 86: 5992, 2001

8. Hosoda H, Kojima M and Kangawa K: Ghrelin and the regulation of food intake and energy balance. Mol Interv 8: 494-503, 2002.

9. Gonzalez-Rey E, Chorny A and Delgado M: Therapeutic action of ghrelin in a mouse model of colitis. Gastroenterology 130 1707-1720, 2006.

10. Waseem T, Duxbury M, Ito H, Ashley SW and Robinson MK: Exogenous ghrelin modulates release of pro-inflammatory and anti-inflammatory cytokines in LPS-stimulated macrophages through distinct signalling pathway. Surgery 143: 334-342, 2008.

11. Dornonville de la Cour C, Lindström E, Norén P and Håkanson R: Ghrelin stimulates gastric emptying but without effect on acid secretion and gastric endocrine cells. Regul Pep 120: 23-32, 2004.

12. Levin F, Edholm T, Schmidt PT, Grybäck P, Jacobsson H, Dergerblad M, Höybye C, Holst JJ, Hellström PM and Näslund E: Ghrelin stimulates gastric emptying and hunger in normal weight humans. J Clin Endocrinol Metab 91: 3279-3280, 2006.

13. Tack J, Depoortere I, Bisschops R, Delporte C, Coulie B, Meulemans A, Janssens J and Peeters T: Influence of ghrelin on interdigestive gastrointestinal motility in humans. Gut 55: 327-333, 2006.
14. Ariga H, Tsukamoto K, Chen C, Mantyh C, Pappas TN and Takahashi T: Endogenous acyl gherlin is involved in mediating spontaneous phase III-like contractions in the rat stomach. Neurogastroenterol Motil 19: 675-680, 2007.

15. Ariga H, Nakade Y, Tsukamoto K, Imai K, Mantyh C, Pappas TN and Takahashi $\mathrm{T}$ : Ghrelin accelerates gastric emptying via early manifestation of antro-pyloric coordination in conscious rats. Regul Pep 146: 112-116, 2008.

16. Tümer C, Oflazoglu HD, Obay BD, Kelle M and Tasdemir E: Effects of ghrelin on gastric myoelectrical activity and gastric emptying in rats. Regul Pep 146: 26-32, 2008.

17. Fukuda H, Mizuta Y, Isomoto H, Takeshima F, Ohnita K, Ohba K, Omagari K, Taniyama K and Kohno S: Ghrelin enhances gastric motility through direct stimulation of intrinsic neural pathways and capsaicin-sensitive afferent neurones in rats. Scand J Gastroenterol 39: 1209-1211, 2004.

18. Edholm T, Levin F, Hellerström PM and Schmidt PT: Ghrelin stimulates motility in the small intestine of rats. Regul Pep 121: 25-30, 2004

19. Tabbe JJ, Mronga S, Tebbe CG, Oertmann E, Arnold R and Schäfer K: Ghrelin-induced stimulation of colonic propulsion is dependent on hypothalamic neuropeptide Y1- and corticotrophinreleasing factor 1 receptor activation. J Neuroendocrinol 17: 570-576, 2005.

20. Ohno T, Kamiyama Y, Aihara R, Nakabayashi T, Mochiki E, Asao T and Kuwano H: Ghrelin does not stimulate gastrointestinal motility and gastric emptying: an experimental study of conscious dogs. Neurogastroenterol Motil 18: 129-135, 2006.

21. Karmiris K, Koutroubakis I, Xidakis C, Polychronaki M, Voudouri T and Kouroumalis EA: Circulating levels of leptin, adiponectin, resistin, and gherlin in inflammatory bowel disease. Inflamm Bowel Dis 12: 100-105, 2006.

22. Ripollés PB, Nazih H, Bourreille A, Segain JP, Huvelin JM, Galmiche JP and Bard JM: Altered lipid, apolipoprotein and lipoprotein profiles in inflammatory bowel diseases: consequences on the cholestrol efflux capacity of serum using Fu5AH cell system. Metabol 55: 980-988, 2006.

23. Ates Y, Degertekin B, Edril A, Yaman H and Dagalp K: Serum gherlin levels in inflammatory bowel disease with relation to disease activity and nutrition status. Dig Dis Sci 53: 2215-2221 2008.

24. Selimoglu MA, Altinkaynak S, Ertekin V and Akcay F: Serum ghrelin levels in children with celiac disease. J Clin Gastroenterol 40: 191-194, 2006.

25. Corazza GR, Di Sario A, Sacco G, Zoli G, Treggiari EA and Brusco G: Subclinical coeliac disease: an anthropometric assessment. J Intern Med 236: 183-187, 1994.

26. Capristo E, Farnetti S, Mingrone G, Certo M, Greco AV, Addolorato $\mathrm{G}$ and Gasbarrini G: Reduced plasma ghrelin concentration in celiac disease after gluten-free diet treatment. Scand J Gastroenterol 40: 430-436, 2005.

27. Peracchi M, Conte D, Terrani C, Pizzinelli S, Gebbia C, Cappiello V, Spada A and Bardella MT: Circulating ghrelin levels in celiac patients. Am J Gastroenterol 98: 2474-2478, 2003.

28. Lanzini A, Magni P, Petroni ML, Motta M, Lanzarotto F, Villanacci V, Amato M, Mora A, Bertolazzi S, Benini F and Ricci C: Circulating ghrelin level is increased in coeliac disease as in functional dyspepsia and reverts to normal during glutenfree diet. Aliment Pharmacol Ther 23: 907-913, 2006.

29. Capristo E, Addolorato G, Mingrone G, De Gaetano A, Greco AV and Tataranni PA: Changes in body composition, substrate oxidation, and resting metabolic rate in adult coeliac disease patients after 1-year gluten-free diet treatment. Am J Clin Nutr 72: 76-78, 2000.

30. Checchi S, Montanaro A, Pasqui L, Ciuoli C, Cevenini G, Sestini F, Fioravanti C and Pacini F: Serum ghrelin as a marker of atrophic body gastritis in patients with parietal cell antibodies. J Clin Endocrinol Metab 92: 4346-4351, 2007.

31. Alnoso N, Granada ML, Salinas I, Reverter JL, Flores L, Ojanguren I, Martinz-Cácerees EM and Sanmarti A: Plasma ghrelin in type 1 diabetic patients with autoimmune atrophic gastritis. Eur J Endocrinol 157: 763-769, 2007.

32. Campana D, Nori F, Pagotto U, De Iasio R, Morselli-Labate AM, Pasquali Corinaldesi R and Tomassetti P: Plasma acylated ghrelin levels are higher in patients with chronic atrophic gastritis. Clin Endocrinol 67: 761-766, 2007.

33. Vila G, Maier C, Riedl M, Nowotny P, Ludvik B, Luger A and Coldi M: Bacterial edotoxin induces biphasic changes in plasma ghrelin in healthy humans. J Clin Endocrinol Metab 92: 3930-3934, 2007 . 
34. Madison LD, Scarlett JM, Levasseur P, Zhu X, Newcomb K Batra A, Bowe D and Marks DL: Prostacyclin signalling regulates circulating ghrelin during acute inflammation. J Endocrinol 196: 263-273, 2008

35. Fetissov SO, Hamze Sinno M, Coëffier M, Bole-Feysot C, Ducrotté P, Hökfelt T and Déchelotte P: Autoantibodies against appetite-regulating peptide hormones and neuropeptides: putative modulation by gut microflora. Nutrition 24: 348-359, 2008.

36. Osawa H, Nakazato M, Date Y, Kita H, Ohnishi H, Ueno H, Shiiya T, Sato K, Ishino Y and Sugano K: Impaired production of gastric ghrelin in chronic gastritis associated with Helicobacter pylori. J Clin Endocrinol Metab 90: 10-16, 2005.

37. Shiotani A, Mivanashi T, Uedo N and Iishi H: Helicobacter pylor infection is associated with reduced circulating ghrelin levels independent of body mass index. Helicobacter 10: 373-378, 2005.

38. Osawa H, Kita H, Ohnishi H, Nakazato M, Date Y, Bowlus CL, Ishino Y, Watanabe E, Shiiya T, Ueno H, Hoshino H, Satoh K and Sugano K: Changes in plasma ghrelin levels, gastric ghrelin production, and body weight after Helicobacter pylori cure. J Gastroenterol 41: 954-961, 2006.

39. Liew PL, Lee WJ, Lee YC and Chen WY: Gastric ghrelin expression associated with Helicobacter pylori infection and chronic gastritis in obese patients. Obes Surg 16: 612-619, 2006.

40. Cindourk M, Yetkin I, Deger SM, Kareakan T, Kan E and Unal S: Influence of $H$. pylori on plasma ghrelin in patients without atrophic gastritis. World J Gastroenterol 13: 1595-1598, 2007.

41. Nishizawa T, Suzuki H, Nomoto Y, Hosoda H, Mori M, Oharat T, Morishita K, Kangawa K and Hibi T: Enhanced plasma ghrelin in patients with functional dysplasia. AP \&TSS 2: 104-110, 2006.

42. Takamori K, Mizuta Y, Takeshima F, Akazawa Y, Isomoto H, Ohnita K, Ohba K, Omagari K, Shikuwa S and Kohno S: Relation among plasma ghrelin level, gastric emptying and psychologic condition in patients with functional dyspepsia. J Clin Gastroenterol 41: 477-483, 2007.

43. El-Salhy M, Lillebø E, Reinemo A and Salmelid L: Ghrelin in patients with irritable bowel syndrome. Int J Mol Med 23: 703-707, 2009.

44. Rauma J, Spångéus A and El-Salhy M: Ghrelin cell density in the gastrointestinal tracts of animal models of type 1 and type 2 diabetes. Histol Histopathol 21: 1-5, 2006.

45. Masaoka T, Suzuki H, Hosoda H, Ota T, Minegishi Y, Nagata H, Kangawa $\mathrm{K}$ and Ishii $\mathrm{H}$ : Enhanced plasma ghrelin levels in rats with streptozotocin-induced diabetes. FEBS Lett 541: 64-68, 2003.

46. El-Salhy M and Rauma J: Low density of ghrelin cells in the oxyntic mucosa correlated to slow gastric emptying in patients with diabetes type 1. Mol Med Rep 2: 893-896, 2009.

47. Irako T, Akamizu T, Hosoda H, Iwakura H, Ariyasu H, Tojo K Tajima $\mathrm{N}$ and Kangawa K: Ghrelin prevents development of diabetes at adult age in streptozotocin-treated newborn rats. Diabetologia 49: 1264-1273, 2006.

48. Binn M, Albert C, Gougeon A, Maereki H, Coulie B, Lemoyne M, Rabasa Lhoret R, Tomasetto C and Poitras P: Ghrelin gastrokinetic action in patients with neurogenic gastroparesis. Peptides 27: 1603-1606, 2006.

49. Murray CDR, Martin NM, Patterson M, Taylor SA, Ghatei MA, Kamm MA, Johnston C, Bloom SR and Emmanuel AV: Ghrelin enhances gastric emptying in diabetic gastroparesis: a double blind, placebo controlled,crossover study. Gut 54: 1693-1698, 2005
50. An JY, Choi MG, Noh JH, Sohn TS, Jin DK and Kim S: Clinical significance of ghrelin concentration of plasma and tumor tissue in patients with gastric cancer. J Surg Res 143: 344-349, 2007.

51. D'Onghia V, Leoncini R, Carli R, Santoro A, Giglioni S, Sorbellini E, Marzocca G, Bernini A, Campagna S, Marinello E, and Vannoni D: Circulating gastrin and ghrelin levels in patients with colorectal cancer: correlation with tumour stage, Helicobacter pylori infection and BMI. Biomed Pharmacother 61: 137-141, 2007.

52. Huang Q, Fan YZ, Ge BJ, Zhu Q and Tu ZY: Circulating ghrelin in patients with gastric or colorectal cancer. Dig Dis Sci 52: 803-809, 2007.

53. Tsolakis AV, Stridsberg M, Grimelius L, Portela-Gomes GM, Falkmer SE, Waldum HI and Janson ET: Ghrelin immunoreactive cells in gastric endocrine tumors and their relation to plasma ghrelin concentration. J Clin Gastroenterol 42: 381-388, 2008.

54. Raffel A, Krausch M, Cupisti K, Gerharz CD, Eisenberger CF and Knoefel WT: Ghrelin expression in neuroendocrine tumours of the gastrointestinal tract with multiple endocrine neoplasia type 1. Horm Metab Res 37: 653-655, 2005.

55. Chan JL, Mun EC, Stoyneva V, Mantozros CS and Goldfine AB: Peptide YY levels are elevated after gastric bypass surgery. Obesity 14: 194-198, 2006.

56. Moringo R, Casamitjana R, Moizé V, Lacy AM, Delgado S, Gomis R and Vidal J: Short-term effects of gastric bypass surgery on circulating ghrelin levels. Obes Res 12: 1108-1116, 2004.

57. Whitson BA, Leslie DB, Kellogg TA, Buchwald H, Billington CJ and Ikramuddin S: Entero-endocrine changes after gastric bypass in diabetic and nondiabetic patients: a preliminary study. J Surg Res 141: 31-39, 2007.

58. Rodieux F, Giusti V, Dálessio DA, Suter M and Tappy L: Effects of gastric bypass and gastric banding on glucose kinetics and gut hormone release. Obesity 16: 298-305, 2008.

59. Uzzan B, Catheline JM, Lagoree C, Airnei G, Bon C, Cohen R, Perret GY, Aparicio T and Benamouzig R: Expression of ghrelin in fundus is increased after gastric banding in morbidly obese patients. Obes Surg 9: 1159-1164, 2007.

60. Schindler K, Prager G, Ballaban T, Kretschmer S, Reiner R, Buranyi B, Mair C, Luger A and Ludvik B: Impact of laparpscopic adjustable gastric banding on plasma ghrelin, eating behaviour and body weight. Eur J Clin Invest 34: 549-454, 2004.

61. Adami GF, Cordera R, Marinari G, Lamerini G, Andraghetti G and Scopinaro N: Plasma Ghrelin concentration in the short-term following biliopancreatic diversion. Obes Surg 13: 889-892, 2003.

62. Langer FB, Reza Hoda MA, Bohdjalian A, Felberbaur FX, Zacherl J, Wenzl E, Schindler K, Lunger A, Ludvik B and Prager G: Sleeve gastrectomy and gastric banding: effects on plasma ghrelin levels. Obes Surg 15, 1501-1502, 2005.

63. Santoro S, Milleo FQ, Malzoni CE, Klajneer S, Borges PC, Santo MA, Campos FG and Artoni RF: Enterohormonal changes after digestive adaptation: five-year results of surgical proposal to treat obesity and associated diseases. Obes Surg 18: 17-26, 2008.

64. Tack J, Depoortere I, Bisschops R, Verbeke K, Janssens J and Peeters T: Influence of ghrelin on gastric emptying and mealrelated symptoms in idiopathic gastroparesis. Aliment Pharmacol Ther 22: 847-853, 2005. 